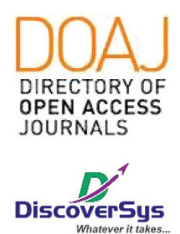

Published by DiscoverSys

\section{Potensi FuMA stem cells, kombinasi fukoidan dan Bone Marrow Stem Cells (BMSCs), sebagai penatalaksanaan mutakhir pada Infark Miokard Akut}

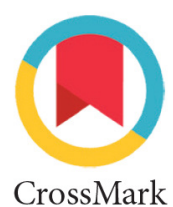

\author{
Agung Bagus Sista Satyarsa', Sang Ayu Arta Suryantari ${ }^{1}$, \\ Putu Gupta Arya Gumilang ${ }^{1}$, Ni Nyoman Ayu Dewi ${ }^{2 *}$
}

\section{ABSTRACT}

Introduction: Acute myocardial infarction (AMI) is the leading cause of death worldwide. One of the causes of high morbidity and mortality is progressive and irreversible nature of the disease and current treatments are still not optimal in resolving these problems. Thus, this paper aims to describe the potential effect of combination of fucoidan and bone marrow stem cells (namely FuMA stem cells) as the novel management of AMI.

Method: The method used in our paper was literature searching by including the keywords of AMI, BMSCs, and fucoidan.

Result: Fucoidan from brown seaweed has shown a great potential effect as anti-inflammatory, anti-coagulant, anti-atherogenic, anti- oxidant, and anti-fibrotic. It limits the infarct area and increases SDF-1, CXCR4 and Akt expression as well as LVEF. However, fucoidan has not been able to regenerate cardiomyocyte cells in AMI. It takes a combination of BMSCs that have been shown to prevent the expansion of infarction area and improve post-infarction function. Conclusion: Thus, FuMA stem cells hold a great potential novel therapy for AMI. Further studies are needed to unveil the potential of FuMA stem cells in AMI management.

Keywords: Acute myocardial infarction, Bone marrow stem cells (BMSCs), Fucoidan, Cells regeneration therapy

Keywords: Acute myocardial infarction, Bone marrow stem cells (BMSCs), Fucoidan, Cells regeneration therapy

Cite This Article: Satyarsa, A.B.S., Suryantari, S.A.A., Gumilang, P.G.A., Dewi, N.N.A. 2019. Potensi FuMA stem cells, kombinasi fukoidan dan Bone Marrow Stem Cells (BMSCs), sebagai penatalaksanaan mutakhir pada Infark Miokard Akut. Intisari Sains Medis 10 (1): $174-180$. DOl: 10.1556/ism.v10i1.300

\title{
ABSTRAK
}

'Program Studi Pendidikan Dokter, Fakultas Kedokteran Universitas Udayana

${ }^{2}$ Departemen Biokimia, Fakultas Kedokteran, Universitas Udayana

${ }^{*}$ Corresponding: Ni Nyoman Ayu Dewi; Departemen Biokimia, Fakultas Kedokteran, Universitas Udayana; ayu.dewi@unud.ac.id
Latar Belakang: Infark miokard akut (IMA) adalah penyebab utama kematian di dunia. Salah satu penyebab morbiditas dan mortalitas yang tinggi adalah sifat penyakit yang progresif dan ireversibel serta perawatan saat ini masih belum optimal dalam menyelesaikannya. Artikel ini bertujuan untuk menjelaskan potensi kombinasi dari fukoidan dan sel induk sumsum tulang (BMSCS) (FuMA stem cells) sebagai manajemen terbaru IMA.

Metode: Metode yang digunakan dalam artikel ini adalah pencarian literatur dengan memasukkan kata kunci dari IMA, BMSCs, dan fukoidan.

Hasil: Fukoidan dari rumput laut coklat telah menunjukkan potensi besar sebagai antiinflamasi, antikoagulan, antiaterogenik, antioksidan, antifibrotik dan membatasi area infark dan peningkatan ekspresi SDF-1, CXCR4, dan Akt serta LVEF. Namun, fukoidan belum mampu meregenerasi sel kardiomiosit pada IMA. Oleh karena itu dibutuhkan kombinasi dengan BMSCs; BMSCs telah terbukti dapat mencegah perluasan area infark dan memperbaiki fungsi miokard pasca infark.

Simpulan: Dengan demikian, FuMA stem cells memiliki potensi besar sebagai terapi baru yang efektif dari IMA. Penelitian lebih lanjut sangat diperlukan untuk mengungkap potensi FuMA stem cells dalam manajemen IMA.

Kata kunci: Infark Miokard Akut, Bone marrow stem cells (BMSCS), Fukoidan, Terapi regenerasi sel

Cite Pasal ini: Satyarsa, A.B.S., Suryantari, S.A.A., Gumilang, P.G.A., Dewi, N.N.A. 2019. Potensi FuMA stem cells, kombinasi fukoidan dan Bone Marrow Stem Cells (BMSCs), sebagai penatalaksanaan mutakhir pada Infark Miokard Akut. Intisari Sains Medis 10 (1): 174-180. D0I: 10.1556/ism.v10i1.300

\section{PENDAHULUAN}

Penyakit kardiovaskuler merupakan penyakit tidak menular yang merupakan penyebab kematian utama di dunia saat ini. ${ }^{1}$ Penyakit ini juga merupakan permasalahan kesehatan global yang berkontribusi atas 41\% kematian di dunia dan 20\% beban penyakit global. ${ }^{2}$ Berdasarkan data statistik dari World Health Organisation (WHO) pada tahun 2015, bahwa dari sebesar 58 juta kematian di dunia, 17.7 juta disebabkan oleh penyakit 
kardiovaskuler. Salah satu penyakit kardiovaskuler yang berkontribusi atas peristiwa tersebut adalah infark miokard. Infark miokard adalah nekrosis miokard (merupakan salah satu proses kematian sel yang dipengaruhi berbagai faktor patologis) yang berkembang cepat oleh karena ketidaksinambungan antara suplai dan kebutuhan oksigen otot-otot jantung. Hal ini biasanya disebabkan oleh ruptur plak yang kemudian diikuti oleh pembentukan trombus oleh trombosit. ${ }^{1,2}$

Pada tahun 2004, infark miokard akut merupakan penyebab kematian utama di dunia. ${ }^{1,2}$ Terutama pada negara berpenghasilan rendah, dengan angka mortalitas 2.470 .000 (35\%) pada tahun 2014. Direktorat Pelayanan Medik Indonesia melaporkan bahwa pada tahun 2007 jumlah pasien penyakit jantung yang menjalani rawat inap dan rawat jalan di rumah sakit di Indonesia adalah 239.548 jiwa. Kasus terbanyak adalah penyakit jantung iskemik, yaitu 110.183 kasus. Case Fatality Rate (CFR) tertinggi terjadi pada infark miokard akut (13.49\%), diikuti gagal jantung (13.42\%) dan penyakit jantung lainnya (13,37\%).

Berdasarkan data American Heart Association (AHA) tahun 2015, bahwa mortalitas tertinggi pada kejadian infark miokard akut. ${ }^{2}$ Gejala klinis seperti aritmia dan angina dapat memperberat status kegawatdaruratan medis yang dapat menyebabkan gagal jantung. Kejadian tersebut dapat diatasi dengan penatalaksanaan yang cepat dan tepat untuk mempertahankan fungsi kerja jantung. ${ }^{2}$

Tatalaksanaan pada infark miokard akut selama ini meliputi; (1) tatalaksana pre-hospital, (2) tatalaksana di IGD, (3) tatalaksana in-hospital dengan menggunakan strategi invasif dan obatobatan. ${ }^{1}$ Strategi invasif yang digunakan adalah Percutaneous Coronary Intervention (PCI) dan Coronary Artery Bypass Graft (CABG). ${ }^{3}$ Sedangkan strategi obat-obatan yang digunakan meliputi; antikoagulan, fibrinolitik, anti-platelet, aspirin, penghambat reseptor ADP, Morfin Sulfat, oksigen, nitrat, angiotensin-converting enzyme inhibitor (ACE-I), angiotensin-receptor blockers (ARB) dan beta blockers. Dari terapi konvensional tersebut masih belum dapat menghentikan kerusakan miokardium yang progresif dan ireversibel serta masih terdapat efek samping obat. Hal ini tentunya menghambat penatalaksanaan infark miokard akut sehingga memerlukan modalitas yang dapat meminimalkan efek samping serta meningkatkan kualitas terapi secara holistik agar meningkatkan kualitas hidup pasien pasca infark miokard akut. ${ }^{3}$

Penelitian terbaru saat ini dalam penatalaksanaan infark miokard akut beralih ke penggunaan fitofarmaka. Salah satunya fukoidan dari ekstrak rumput laut cokelat yang merupakan fitofarmaka dengan bioaktivitas dan efek klinis sebagai kardioprotektif., ${ }^{4,5}$ Berdasarkan hasil penelitian sebelumnya menyatakan bahwa fukoidan memiliki potensi sebagai antiinflamasi, antikoagulan, antiaterosklerosis, antioksidan, antifibrosis, antikanker, antiviral, proangiogensis dan menjaga keseimbangan ATPase dalam jantung. Berdasarkan hasil penelitian Manzo et al., ${ }^{4}$ bahwa fukoidan juga meningkatkan ekspresi sitokin VEGF dan SDF1a pada daerah reperfusi iskemik. ${ }^{4}$ Hal tersebut membuktikan fukoidan dapat merevaskularisasi dan sebagai neoangiogenesis. ${ }^{5}$

Selain itu, saat ini terapi sel punca juga dilirik sebagai terapi pada infark miokard akut. Salah satunya adalah autologous bone marror stem cells (BMSCs) yang memiliki potensi dalam proses regenerasi pasca infark miokard. BMSCs derivat mesencymal stem cells (MSCs) memiliki kelebihan dari sel punca yang lain yakni dapat berdiferensiasi menjadi sel kardiomiosit dengan sistem parakrin, antiapoptosis dan mudah diperoleh serta mudah diaplikasikan sebagai terapi infark miokard akut. Berbagai penelitian terbaru juga menunjukan potensi BMSCs sebagai pilihan terapi untuk infark miokard akut. BMSCs memiliki potensi dalam melindungi jantung dari perluasan infark dan meningkatkan fungsi jantung serta penurunan gejala klinis pasca infark. Hal tersebut didukung dari hasil penelitian Sanghi et al., pada clinical trial phase I ditemukan peningkatan secara signifikan dari fungsi ventrikel kiri jantung (LVEF, LV end systolic, revaskularisasi) pasca infark miokard akut dengan induksi BMSCs secara intrakoroner pada pasien ASTAMI, BOOST, REPAIR-AMI, BONAMI, SCAMI, CADUCEUS dan uji klinik lainnya. Keunggulan BMSCs juga memiliki karekteristik sebagai stem cells yang diambil langsung dari tubuh si penderita sehingga menghindarkan dari risiko penolakan imun. ${ }^{6,7}$

Namun masih terdapat keterbatasan BMSCs dalam terapinya, yakni sel punca akan berdifirensiasi secara lambat pada daerah infark disebabkan mediator inflamasi, luas daerah infark dan fibrosis pada miokardium yang mengakibatkan efektivitas terapi rendah. ${ }^{8,9}$ Kekurangan tersebut diatasi dengan bioaktivitas fukoidan. Fukoidan juga berpotensi sebagai antiinflamasi; fukoidan merupakan faktor kemotaksis yang meningkatkan ekspresi SDF-1a secara signifikan pasca injeksi secara intravena sehingga meningkatkan proliferasi BMSCs melalui FAK dan PI3k-Akt cascade ${ }^{4,5}$ Pemberian fukoidan juga dapat menghambat ROS (Reactive Oxygen Species) sehingga terapi stem cells yang dijalani dapat efektif dan komprehensif. ${ }^{10}$

Berdasarkan potensi tersebut, maka kombinasi fukoidan dan BMSCs sebagai FuMA stem cells 
dapat mengembalikan fungsi kerja jantung secara baik pasca infark miokard akut. Dengan demikian, FuMA stem cells yang memiliki berbagai keunggulan berpotensi besar sebagai penataksanaan mutakhir pada infark miokard akut. Artikel ini menjelaskan kombinasi fukoidan dan BMSCs sebagai penatalaksanaan mutakhir pada infark miokard akut.

\section{PEMBAHASAN}

\section{Patogenesis Infark Miokard Akut}

Semakin meningkatnya angka harapan hidup menyebabkan pula peningkatan insiden ischemic heart disease (IHD) di dunia. Infark Miokard Akut (IMA) merupakan penyebab utama congestive heart failure (CHF) dan kematian. Kemampuan kardiomiosit untuk melakukan regenerasi berkurang setelah terjadi infark miokard. ${ }^{1}$

Patogenesis IMA secara umum didasari oleh adanya ateroskeloris pembuluh darah koroner. Nekrosis miokard akut hampir selalu terjadi akibat penyumbatan total arteri koronaria oleh trombus yang terbentuk pada plak aterosklerosis yang tidak stabil, juga sering mengikuti ruptur plak pada arteri koroner dengan stenosis ringan (50-60\%). ${ }^{2}$ Kerusakan miokard terjadi dari endokardium ke epikardium, menjadi progresif dan ireversibel dalam 3-4 jam. Secara morfologis, IMA dapat terjadi transmural atau sub-endokardial. IMA transmural mengenai seluruh dinding miokard dan terjadi pada daerah distribusi suatu arteri koroner. Sebaliknya pada IMA sub-endokardial, nekrosis terjadi hanya pada bagian dalam dinding ventrikel. Patofisiologi dua jenis kelainan yang terjadi pada IMA adalah komplikasi hemodinamik dan aritmia. Segera setelah terjadi IMA daerah miokard setempat akan memperlihatkan penonjolan sistolik (diskinesia) dengan akibat penurunan ejection fraction, isi sekuncup (stroke volume) dan peningkatan volume akhir distolik ventrikel kiri. Tekanan akhir diastolik ventrikel kiri meningkat dengan akibat tekanan atrium kiri juga naik. Peningkatan tekanan atrium kiri di atas $25 \mathrm{mmHg}$ yang lama akan menyebabkan transudasi cairan ke jaringan interstisium paru (gagal jantung). Pemburukan hemodinamik ini bukan saja disebabkan karena daerah infark, tetapi juga daerah iskemia di sekitarnya. ${ }^{2,11}$

Pada IMA juga terjadi pelepasan Troponin, P-selectin, C-kreatinin, CK-MB dalam 12 jam pasca infark. Hal tersebut dapat dilihat dari kejadian STEMI (ST Elevation Myocardial Infarction) dan NSTEMI. ${ }^{2}$ Peningkatan pelepasan mediator inflamasi pada IMA juga terjadi, seperti IL-6 dan TNFa serta peningkatan ekspresi NF$\mathrm{k} \beta$, ROS (Reactive Oxygen Species), dan cascade koagulasi yang dapat menyebabkan penyumbatan aliran darah sehingga asupan $\mathrm{O}_{2}$ berkurang hingga menyebabkan shok kardiogenik. ${ }^{11}$

Sebagai dampak dari IMA, sering terjadi perubahan bentuk serta ukuran ventrikel kiri dan tebal jantung ventrikel baik yang terkena infark maupun yang tidak infark. Perubahan tersebut menyebabkan remodeling ventrikel yang nantinya mempengaruhi fungsi ventrikel dan timbulnya aritmia. Perubahan-perubahan hemodinamik IMA ini tidak statis. Daerah diskinetik akibat MA akan menjadi akinetik, karena terbentuk jaringan parut yang kaku yang bersifat progesif dan ireversibel. Miokardium yang terdiri atas banyak kardiomiosit merupakan jenis sel yang sudah tidak dapat berdiferensiasi lagi. Respons sel tersebut terhadap cedera berupa hipertrofi namun tidak mengalami hiperplasia. Sistem perbaikan alamiah akan memperbaiki miosit yang mengalami kerusakan, akan tetapi mekanisme itu tidak bekerja pada kerusakan sel yang lebih lanjut. ${ }^{11,12}$

Penyulit mekanis seperti ruptur septum ventrikel, regurgitasi mitral akut dan aneurisma ventrikel akan memperburuk faal hemodinamik jantung. Aritmia merupakan penyulit IMA tersering dan terjadi terutama pada jam-jam pertama setelah serangan. Hal ini disebabkan oleh perubahan masa refrakter, daya hantar rangsangan dan kepekaaan terhadap rangsangan. Sistem saraf otonom juga berperan besar terhadap terjadinya aritmia. Pasien IMA inferior umumnya mengalami peningkatan tonus parasimpatis dengan akibat kecenderungan bradiaritmia meningkat sehingga mempertinggi kecenderungan fibrilasi ventrikel dan perluasan infark. ${ }^{12}$

\section{Mekanisme Konstruksi dan Administrasi FuMA stem cells}

Fukoidan adalah polisakarida tersulfatasi dari rumput laut coklat yang umumnya tersedia yaitu glikosaminoglikan (GAGs) berupa F-fukoidan. Terdapat lebih dari 95\% fukoidan di laut yang tersusun dari ester tersulfatasi L-fucose dan U-Fukoidan. Fukoidan didapat dari ekstrak alga coklat dan rumput laut seperti: Ascophyllum nodosum, Fucus vesiculous, Sargassum dan sejenisnya. Alga coklat dibersihkan dengan air mengalir dan dijemur dibawah sinar matahari selama 12 jam, kemudian ditumbuk menjadi bentuk bubuk. Selanjutnya, dilakukan dispigmentasi dengan aseton selama 24 jam dan diekstraksi air hangat pada suhu $90^{\circ}-95^{\circ} \mathrm{C}$ selama 3-4 jam sampai $1 / 4$ konsentrasinya. Setelah didinginkan dan ditambahkan etanol pada suhu $4^{\circ} \mathrm{C}$, dilakukan sentrifugasi. Presipitat dikeringkan dengan dietil eter sehingga diperoleh 95\% ekstrak fukoidan, sulfat polisakarida. Dosis efektif sebagai terapi IMA sebesar $200 \mathrm{mg} / \mathrm{kg}$ yang tidak memiliki efek toksik 
maupun efek samping. Administrasi fukoidan dapat dilakukan secara intravena dan dilaksanakan pasca infark. Efek klinis fukoidan setelah administrasi secara intravena yakni 1 jam dengan terapheutic window selama 12 jam. Setelah pasien sadar, fukoidan dapat diberikan secara oral dengan dosis yang sama. Pemberian fukoidan dilajutkan selama 1 bulan sehingga dapat dikombinasikan dengan sel punca untuk memaksimalkan efek klinisnya. ${ }^{13}$

Sebelum administrasi BMSCs ke jantung, pertama dilakukan pengambilan BMSCs dari pasien (autologous). Pengambilan BMSCs dilakukan pada krista iliaka yang telah didesinfeksi dengan alkohol $70 \%$ untuk mendapatkan bone marrow. ${ }^{7}$ BMSCs lalu disaring dengan microfilter kemudian disimpan dikantung yang mengandung citrate phosphate dextrose-adenin (CPD-A) sebagai antikoagulan dan bahan pengawet. Sel dikultur dalam media kultur DMEM yang mengandung $1000 \mathrm{mg} / \mathrm{L} \mathrm{D}$-glucose, L-glutamin, dan $110 \mathrm{mg} / \mathrm{L}$ sodium piruvat, dan $10 \%$ fetal bovine serum (FBS) dan diinkubasi selama satu minggu pada suhu $37^{\circ} \mathrm{C}$ dengan aliran oksigen $20 \%$ dan $\mathrm{CO}_{2} 5 \%$. Kultur dicuci dengan PBS, dan diisi kembali dengan medium kultur yang segar setiap 3 hari. $^{3}$ Botol kultur tersebut diobservasi untuk evaluasi adanya penempelan sel-sel yang bernukleus. Saat sel kultur telah penuh (confluent), sel tersebut dilepaskan dari penempelan di plastik botol kultur dengan tripsin 0.25\%-EDTA $1 \mathrm{mM}$ dan dilakukan sub-kultur ke beberapa botol kultur. Selanjutnya administrasi BMSCs secara intrakoroner dilakukan melalui kateterisasi jantung bagian kiri. Sebuah kawat penuntun diletakkan pada bagian distal left anterior descending artery melalui 6 french guiding catheter. ${ }^{9}$ Teknik stop-flow digunakan untuk menyalurkan BMSCs ke daerah infark. Selama pelaksanaan teknik ini sebuah balon dipompa secara berkala selama kurang lebih 6 kali dengan tekanan yang rendah. Sekitar 40-50 mililiter BMSCs secara perlahan diinjeksikan intrakoroner. Waktu yang diperlukan untuk menyelesaikan prosedur ini sekitar 45-60 menit. ${ }^{7-10}$

Prosedur adminitrasi secara intrakoroner lebih dianjurkan karena memberikan waktu dan kesempatan yang lebih banyak kepada BMSCs untuk terdistribusi ke daerah-daerah yang mengalami infark serta menghindari terjadinya penumpukan alokasi BMSCs. ${ }^{8}$ Prosedur administrasi ini juga lebih mudah dilakukan dan lebih aman dibandingkan dengan administrasi secara intramiokard yang lebih invasive. $^{7,8}$

\section{Potensi FuMA stem cells sebagai Penatalaksanaan Mutakhir IMA}

FuMA stem cells memiliki potensi besar sebagai penatalaksanaan pada IMA, ditunjang dari berbagai fakta dan penelitian hingga clinical trial $I I^{3,4}$ Perhatian utama dalam penatalaksanaan IMA saat ini adalah mencegah kematian sel, meminimalkan keluhan dan stress serta membatasi perluasan kerusakan miokard. Proses inflamasi memainkan peranan penting dalam patogenesis IMA. Hal tersebut dapat dihambat dengan bioaktivitas fukoidan sebagai antiinflamasi. Administrasi fukoidan secara intravena memiliki bioaktivitas dan efek klinis sebagai antioksidan, antiaterosklerosis, antikoagulan, antikanker, antifibrosis dan proangiogenesis sehingga fukoidan berpotensi sebagai kardioprotektif pasca infark. ${ }^{14}$ Berdasarkan hasil penelitian oleh Fitton et al., bahwa fukoidan dapat menghambat sitokin proinflamasi (IL-6, TNF- $\alpha$, CXCL2, dan NF-k $\beta$ ) yang secara signifikan pada serum tikus kondisi IMA. ${ }^{15}$ Fukoidan juga menurunkan $\mathrm{CK}-\mathrm{MB}$ dan troponin pasca infark melalui penghambatan spesifik P-selectin. Ditemukan juga potensi fukoidan yang terlihat dalam meningkatkan fungsi ejeksi ventrikel kiri jantung dan mengurangi ukuran daerah iskemia sebesar $30-40 \%$ pada IMA. ${ }^{4}$ Hal tersebut dapat mencegah progresivitas dan ireversibilitas pasca IMA. ${ }^{4,10}$

Fukoidan dapat berfungsi sebagai antioksidan melalui berbagai mekanisme. ${ }^{16,17}$ Salah satunya, fukoidan menghambat infiltrasi dari limphosit polymorphonuclear (PMN) yang dapat merusak jaringan dan memicu pengeluaran radikal bebas. ${ }^{14}$ Fukoidan juga dapat sebagai antiaterosklerosis yakni meningkatkan secara signifikan sintesis High Density Lipoprotein (HDL) dengan menurunkan sintesis Low Density Lipoprotein (LDL)., ${ }^{45}$ Selain itu, fukoidan meningkatkan fibroblast growth faktor-2 (FGF2) dan sitokin vascular endothelial growth factor (VEGF) dalam proses angiogenesis sehingga terjadi neovaskularisasi dan menghambat pembentukan jaringan parut. Hal tersebut dibuktikan dari hasil penelitian Manzo et al. (2011), ${ }^{4}$ dan Lee et al. (2016), ${ }^{14}$ bahwa fukoidan berpotensi mencegah mesenchymal stem cells (MSCs) dari stres oksidatif dan meningkatkan ekspresi sitokin VEGF sehingga dapat meningkatkan viabilitas, migrasi, proliferasi, pertumbuhan dan ketahanan MSCs secara in vivo. Didukung dari hasil penelitian Han et al. (2015), ${ }^{10}$ bahwa fukoidan meningkatkan migrasi, proliferasi, dan ketahanan sel punca mejadi kardiomiosit melalui interaksinya dengan SDF-1CXCR4. Dengan potensi tersebut fukoidan dapat meningkatkan mekanisme kerja dan efek klinis dari sel punca.

Sel punca merupakan suatu terapi yang multi potensial dan dapat berdiferensiasi menjadi berbagai tipe sel termasuk sel-sel jantung. Salah satunya autologous BMSCs yang banyak dimanfaatkan 
sebagai marker MSCs dan mengekspresikan GATA-4, SDF-1, CXCR4 yang berfungsi untuk meregenerasi sel kardiomiosit pasca infark. ${ }^{8,9}$

Mekanisme kerja BMSCs setelah diadministrasi secara intrakoroner yakni memberi efek proteksi dengan mekanisme parakrin yang melibatkan pelepasan beberapa sitokin yang mampu melindungi sel. Mekanisme parakrin juga mampu meningkatkan kepadatan atau densitas pembuluh darah mikro dan mengurangi area fibrotik pada miokardium yang mengalami infark secara signifikan. Berdasarkan pewarnaan histologis pada studi eksperimental juga menunjukkan pertambahan jumlah pembuluh darah mikro pada area iskemik. Hal ini mempertahankan kapasitas kontraksi miokardium, menghalangi proses apoptosis dan merangsang angiogenesis serta regenerasi sel kardiomiosit. ${ }^{18}$

BMSCs juga meningkatkan aktivasi cell survival factors seperti Akt dibawah kondisi anoksia dan peningkatan endothelial nitric oxide synthase (eNOS). Akt memiliki peran dalam proses pemberian sinyal antiapoptosis karena mampu mencegah fragmentasi deoxyribo nucleic acid (DNA). Akt memiliki target faktor proapoptosis seperti Ced9/bcl2 dan Ced-3 kaspase. Selain itu, Akt juga memodulasi metabolisme glukosa intraseluler sehingga dapat meningkatkan produksi energi selama kondisi anoksia. Efek antiapoptosis yang dimiliki Akt berkontribusi terhadap berkurangnya area yang mengalami infark. ${ }^{8-10}$

Anoxic preconditioning (AP) dari BMSCs mampu meningkatkan efektivitasnya melalui mekanisme antiapoptosis dalam melindungi kardiomiosit dari iskemia. AP memberikan proteksi terhadap jantung dengan meningkatkan ekspresi eNOS dan inducible nitric oxide synthase (iNOS) merupakan enzim yang berperan dalam peningkatan produksi nitric oxide (NO). Hal tersebut memiliki peranan dalam merelaksasikan sel-sel otot halus vaskuler yang menyebabkan vasodilatasi. Vasodilatasi ini mengakibatkan tercukupinya suplai darah ke jaringan jantung sehingga infark selanjutnya dapat dihindari. ${ }^{19}$

Beberapa sitokin juga dihasilkan oleh BMSCs seperti VEGF, basic fibroblast growth factor (bFGF), insulin-like growth factor-1 (IGF-1), interleukin$1 \beta$ (IL-1 $\beta)$, platelet derived growth factor (PDGF), dan stromal cell-derived factor-1 (SDF-1) yang kenaikannya lebih tinggi pada kondisi hipoksia dibandingkan normoksia. ${ }^{20}$

Penelitian menunjukkan potensi BMSCs dalam mengekspresi SDF-1 yang memiliki efek protektif terhadap kardiomiosit dari iskemia. ${ }^{8}$ SDF-1 mengaktifkan pertumbuhan dan survival signaling pathway pada kardiomiosit secara langsung dengan berikatan pada reseptor spesifik CXCR $4 .^{8}$ SDF-1CXCR4 juga dapat meningkatkan regenerasi sel jantung melalui mekanisme perekrutan stem cells hematopoietik dan sel progenitor ke daerah infark, menurunkan ukuran infark, memicu angiogenesis dan secara keseluruhan meningkatkan fungsi ventrikel kiri jantung. Interaksi BMSCs dengan SDF-1 dan CXCR4 penting untuk menstimulasi viabilitas, migrasi, proliferasi, ketahanan dan diferensiasi sel progenitor secara in vitro maupun in vivo. ${ }^{9,18}$

Hasil sebuah randomized controlled trial (RCT) menyimpulkan BMSCs sebagai terapi adjuvant bagi pasien yang tidak menunjukkan peningkatan terhadap pemberian terapi konvensional dan pasien yang tidak memenuhi syarat untuk revaskularisasi, seperti PCI. ${ }^{20,21}$ Ditambahkan juga berdasarkan dari hasil penelitian eksperimental menunjukkan bahwa transfer stem cells dan sel-sel progenitor yang berasal dari sumsum tulang meningkatkan kerja jantung setelah IMA. ${ }^{22}$ Terlihat pada peningkatkan secara signifikan dari fraksi ejeksi ventrikel kiri (LVEF) sebesar 20-30\% pada pasien IMA. Selain itu, BMSCs juga dapat menjadi terapi gagal jantung iskemik yang telah dibuktikan pada uji klinis fase I dan II. ${ }^{23}$ Terapi ini telah terbukti aman dan layak serta efek klinis yang menjanjikan. Efek klinis lainnya dari BMSCs juga dalam hal perfusi regional dan fungsi global jantung pada IMA dengan menurunkan ruptur septum ventrikel, regurgitasi mitral akut dan aneurisma ventrikel sehingga menurunkan kejadian aritmia jantung. BMSCs juga tidak menimbulkan respon imun setelah di administrasikan. $^{24}$

Potensi BMSCs ini akan memiliki efek optimal dalam penatalaksanaan IMA setelah dikombinasi dengan fukoidan., ${ }^{4,10,14}$ Namun, belum ada penelitian yang membandingkan efektivitas terapi antara FuMA stem cells dengan terapi konvensioal. Inovasi terapi ini dapat menjadikan FuMA stem cells bersaing dengan terapi konvensional saat ini. Hal tersebut dapat dilihat dari potensi yang ditawarkan oleh FuMA stem cells, sebagai penatalaksanaan IMA. Oleh sebab itu, penelitian masih diperlukan baik uji klinis dengan tingkatan yang lebih kompleks untuk dapat memberikan bukti ilmiah tervalidasi. Selain itu, diperlukan juga penelitian mengenai efisiensi dan efektivitas inovasi ini dibandingkan terapi konvensional pada penatalaksanaan IMA.

\section{Keunggulan FuMA stem cells sebagai Penatalaksanaan IMA}

Berdasarkan hasil penelitian sebelumnya menyatakan terdapat lima keunggulan utama dari FuMA stem cells dengan manfaat bagi pasien yang tidak dapat disembuhkan dengan terapi konvensional. 
Pertama, terapi menggunakan FuMA stem cells untuk IMA sangat menjanjikan. Data klinis menunjukkan peningkatan hasil terapi dibandingkan dengan terapi konvensional. Suatu penelitian clinical trial II menunjukan hasil bahwa autologous BMSCs memiliki administrasi yang aman dan indeks terapi yang baik pada IMA. ${ }^{8-}$ 10 Kombinasi dengan fukoidan tidak berefek toksik pasca administrasi dan juga meningkatkan efektivitas terapi IMA hingga 88,9\%. ${ }^{4}$

Kedua, FuMA stem cells bekerja multi-target dalam meningkatkan fungsi jantung pasca infark dan mencegah terjadinya gagal jantung. Hal tersebut didukung dari hasil penelitian sebelumnya, bahwa FuMA stem cells menurunkan luas infark, mencegah apoptosis sel, menghambat inflamasi, radikal bebas, koagulasi, trombotik hingga fibrosis miokardium. Selain itu, terjadi peningkatan pada SDF-1a, ATPase, fungsi ejeksi ventrikel kiri (LVEF), proliferasi sel melalui cyclin E, cyclin D1, CDK4 dan CDK2 serta signal kaskade PI3k-Akt-FAK (Focal adhesion kinase) (Gambar 1).

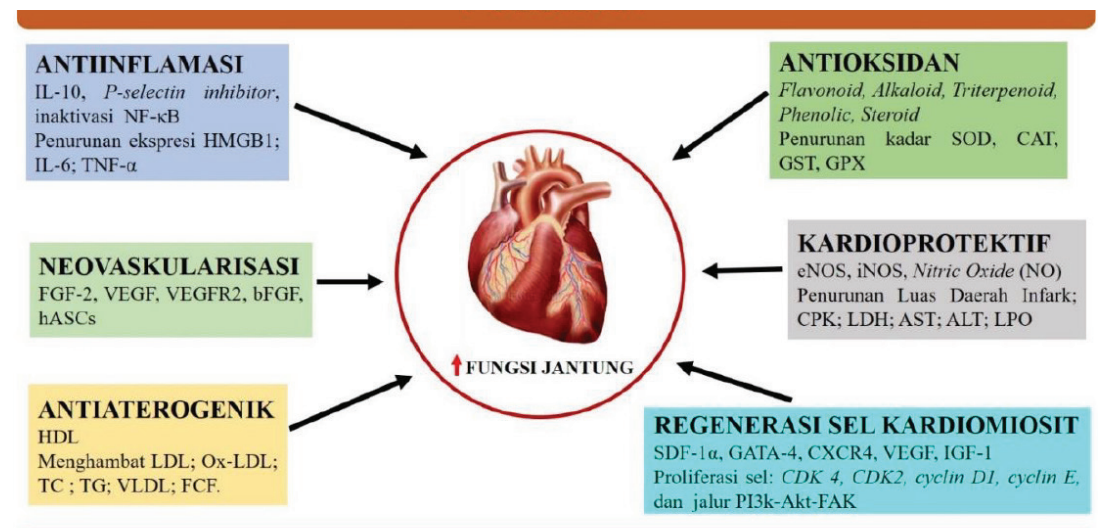

BONE MARROW STEM CELLS (BMSCs)

Gambar 1. Potensi FuMA stem cells (kombinasi fukoidan dan BMSCs) sebagai penatalaksanaan mutakhir pada infark miokard akut

\section{Keterangan:}

FGF-2: fibroblast growth factor-2, VEGF: vascular endothelial growth factor, VEGFR2: vascular endothelial growth factor receptor 2, bFGF: basic fibroblast growth factor, hASCs: Human adipose-derived stem cells, HMGB1: High mobility group box 1 protein, IL-6: Interleukin 6, IL-10: Interleukin 10, TNF- $\alpha$ : Tumor Necrotic Factor $\alpha$, LDL: low density lipoprotein, Ox-LDL: Oxidized low-density lipoprotein, TC: total cholesterol, TG: triglyceride, VLDL: very-low density lipoprotein, FCF: Foam Cell Formation, HDL: high density lipoprotein, eNOS: Endothelial nitric oxide synthase, iNOS: Inducible nitric oxide synthase, NF-Kb: nuclear factor kappa-light-chain-enhancer of activated B cells, CPK: creatine phosphokinase, LDH: lactate dehydrogenase, AST: aspartate transaminase, ALT: alanine transaminase, LPO: lipid peroxidation, SDF-1a: stromal cell-derived factor 1, GATA-4, CXCR4: C-X-C chemokine receptor type 4, IGF-1: insulin-like growth factor-1, CDK: Cyclin-Dependent Kinases, Akt: Protein kinase B, PI3k: Phosphatidylinositol-4,5-bisphosphate 3-kinase, FAK: focal adhesion kinase, SOD; Superoxide dismutase, CAT; catalase, GST; Glutathione-S-transferase, GPX; Glutathione peroxidase.
Ketiga, FuMA stem cells memiliki keunggulan sebagai kardioprotektif pasca IMA.

Kempat, modalitas ini dapat mencegah kemungkinan terjadinya komplikasi IMA dimasa depan sehingga menurunkan angka morbiditas dan mortalitas IMA di dunia.

Kelima, FuMA stem cells memiliki mekanisme konstruksi dan administrasi yang mudah, ekonomis dan efisien untuk diaplikasikan di Indonesia.

\section{Keterbatasan FuMA stem cells sebagai Penatalaksanaan IMA}

Keterbatasan dari FuMA stem cells yaitu pada penerapan pre-klinis dan klinis, terapi berbasis stem cells memiliki efikasi terapi yang terbatas karena rendahnya ketahanan stem cells pada daerah iskemik, terutama pada pasien yang menderita komplikasi kronis yang berada pada kondisi patofisiolgi lebih berat seperti tingginya tingkat radikal bebas, inflamasi berat, dan ketidakseimbangan sitokin. Jadi, untuk mengatasi keterbatasan tersebut, dapat dipertimbangkan penggunaan kombinasi dengan zat aktif fukoidan dari alga cokelat. Terapi MSCs ditambah fukoidan memilki efek secara signifikan dalam meningkatkan migrasi, internalisasi, proliferasi, ketahanan dan vaskularisasi MSCs di daerah iskemia pasca IMA serta meningkatkan SDF-1 dalam melindungi MSCs dari apoptosis, inflamasi dan stress oksidatif. ${ }^{10}$ Dengan demikan, fukoidan dapat melindungi BMSCs sehingga terjadi regenerasi kardiomiosit dan revaskularisasi secara signifikan.

\section{KESIMPULAN}

Berbagai penelitian in vitro maupun in vivo menunjukkan bahwa kombinasi fukoidan dan BMSCs (FuMA stem cells) berpotensi besar sebagai penatalaksanaan mutakhir untuk infark miokard akut. Keunggulan FuMA stem cells adalah mudah diperoleh dan tidak memiliki efek toksik setelah diadministrasikan. Oleh karena itu, FuMA stem cells dapat menurunkan mortalitas kejadian Ischemic Heart Disease (IHD). Namun tentu saja, masih sangat diperlukan penelitian-penelitian lebih lanjut untuk memahami lebih detail mekanisme FuMA stem cells dalam manajemen terapi IMA.

\section{CONFLICT OF INTEREST}

Penulis menyatakan tidak ada conflict of interest.

\section{DAFTAR PUSTAKA}

1. GBD 2013 Mortality and Causes of Death Collaborators. Global, regional, and national age-sex specific all-cause and cause-specific mortality for 240 cause of death, 1990-2013: a systematic analysis for the global burden of disease study 2013.The Lancet. 2015;9963(385):117-71. 
2. Mozaffarian D, Benjamin EJ, Go AS, Arnett DK, Blaha MJ, Cushman M, et al. Executive summary: heart disease and stroke statistics-2016 update: a report from the American Heart Association. Circulation. 2016 Jan 26;133(4):447-54.

3. Hernandez MJ, Christman KL. Designing acellular injectable biomaterial therapeutics for treating myocardial infarction and peripheral artery disease. JACC: Basic to Translational Science. 2017 Apr 24;2(2):212-26.

4. Manzo-Silberman S, Louedec L, Meilhac O, Letourneur D, Michel JB, Elmadbouh I. Therapeutic potential of fucoidan in myocardial ischemia. Journal of cardiovascular pharmacology. 2011 Dec 1;58(6):626-32.

5. Sarlon G, Zemani F, David L, Duong Van Huyen Jp, Dizier B, Grelac F, et al. Therapeutic effect of fucoidan-stimulated endothelial colon-forming cells in peripheral ischemia. Journal of Thrombosis and Haemostasis. 2012 Jan;10(1):3848.

6. Sanghi V, Sethi D, Harris KL, Gupta S, Kar S, Bhatia M, et al. Autologous bone marrow concentrate enriched in progenitor cells-An adjuvant in the treatment of acute myocardial infarction. International Journal of the Cardiovascular Academy. 2016 Jun 1;2(2):77-83.

7. Micheu MM, Dorobantu M. Fifteen years of bone marrow mononuclear cell therapy in acute myocardial infarction. World journal of stem cells. 2017 Apr 26;9(4):68.

8. Samanta A, Afzal MR, Dawn B. Bone Marrow Cell Therapy for Ischemic Heart Disease and the Role of Cardiac Imaging in Evaluation of Outcomes. In: Imaging in Stem Cell Transplant and Cell-based Therapy. Springer. 2017;133-52.

9. Luo L, Tang J, Nishi K, Yan C, Dinh PU, Cores J, et al. Fabrication of synthetic mesenchymal stem cells for the treatment of acute myocardial infarction in mice. Circulation research. 2017 May 26;120(11):1768-75.

10. Han YS, Lee JH, Jung JS, Noh H, Baek MJ, Ryu JM, Yoon YM, Han HJ, Lee SH. Fucoidan protects mesenchymal stem cells against oxidative stress and enhances vascular regeneration in a murine hindlimb ischemia model. International journal of cardiology. 2015 Nov 1; 198:18795.

11. Reed GW, Rossi JE, Cannon CP. Acute myocardial infarction. The Lancet. 2017 Jan 14;389(10065):197-210.

12. Anderson JL, Morrow DA. Acute myocardial infarction. New England Journal of Medicine. 2017 May 25;376(21):2053-64.

13. Ale MT, Mikkelsen JD, Meyer AS. Important determinants for fucoidan bioactivity: A critical review of structurefunction relations and extraction methods for fucosecontaining sulfated polysaccharides from brown seaweeds. Marine drugs. 2011 Oct;9(10):2106-30.

14. Lee JH, Ryu JM, Han YS, Zia MF, Kwon HY, Noh H, et al. Fucoidan improves bioactivity and vasculogenic potential of mesenchymal stem cells in murine hind limb ischemia associated with chronic kidney disease. Journal of molecular and cellular cardiology. 2016 Aug 1; 97:169-79.

15. Fitton J, Stringer D, Karpiniec S. Therapies from fucoidan: An update. Marine drugs. 2015 Sep;13(9):5920-46.
16. Purnama A, Aid-Launais R, Haddad O, Maire M, Mantovani D, Letourneur D, et al. Fucoidan in a 3D scaffold interacts with vascular endothelial growth factor and promotes neovascularization in mice. Drug delivery and translational research. 2015 Apr 1;5(2):187-97.

17. Hwang PA, Hung YL, Phan NN, Chang PM, Li KL, Lin YC. The in vitro and in vivo effects of the low molecular weight fucoidan on the bone osteogenic differentiation properties. Cytotechnology. 2016 Aug 1;68(4):1349-59.

18. Cahill TJ, Choudhury RP, Riley PR. Heart regeneration and repair after myocardial infarction: translational opportunities for novel therapeutics. Nature Reviews Drug Discovery. 2017 Oct;16(10):699.

19. Beitnes JO, Hopp E, Lunde K, Solheim S, Arnesen H, Brinchmann JE, et al. Long-term results after intracoronary injection of autologous mononuclear bone marrow cells in acute myocardial infarction: the astami randomised, controlled study. Heart. 2009; 95:1983-9.

20. Wöhrle J, von Scheidt F, Schauwecker P, Wiesneth M, Markovic S, Schrezenmeier $\mathrm{H}$, et al. Impact of cell number and microvascular obstruction in patients with bone-marrow derived cell therapy: final results from the randomized, double-blind, placebo controlled intracoronary Stem Cell therapy in patients with Acute Myocardial Infarction (SCAMI) trial. Clinical Research in Cardiology. 2013 Oct 1;102(10):765-70.

21. Sürder D, Manka R, Moccetti T, Lo Cicero V, Emmert MY, Klersy C, et al. Effect of bone marrow-derived mononuclear cell treatment, early or late after acute myocardial infarction: twelve months CMR and long-term clinical results. Circulation research. 2016 Jul 22;119(3):481-90.

22. Ji ST, Kim H, Yun J, Chung JS, Kwon SM. Promising Therapeutic Strategies for Mesenchymal Stem Cell-Based Cardiovascular Regeneration: From Cell Priming to Tissue Engineering. Stem Cells International Hindawi. 2017;(2017):1-13.

23. Jiang C, Zheng D, Feng YL, Guo J, Li HR, Zhang AD. Short-and Long-term Therapeutic Efficacies of Intravenous Transplantation of Bone Marrow Stem Cells on Cardiac Function in Rats with Acute Myocardial Infarction: A Meta-analysis of Randomized Controlled Trials. Chinese Medical Sciences Journal. 2016 Sep 1;31(3):142-8.

24. Mura M, Ciuffreda M, Pisano F, Malpasso G, Gnecchi M. Improving the Cardioprotective and Regenerative Properties of Bone Marrow Derived Mesenchymal Stem Cells Through the Overexpression of IGF1 and BMP2. Cytotherapy. 2016 Jun 1;18(6): S81.

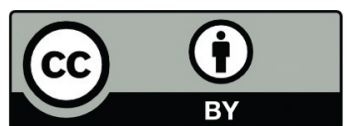

This work is licensed under a Creative Commons Attribution 